\title{
RECUPERANT LA MEMÒRIA HISTÒRICA: MARIA CARRATALÀ, UNA TRADUCTORA TEATRAL DE PREGUERRA*
}

\author{
RECOVERING HISTORICAL MEMORY: \\ MARIA CARRATALÀ, A PRE-WAR \\ THEATRE TRANSLATOR
}

\author{
TERESA Julio \\ Universitat de Vic - UCC \\ tjulio@uvic.cat
}

Resum: Entre 1933 i 1935, Maria Carratalà fou presidenta del Lyceum Club de Barcelona, centre de trobada de dones amb inquietuds artístiques i intel-lectuals. La seva amistat amb l'Artur Carbonell, director teatral i, més tard, catedràtic de l'Institut del Teatre de Barcelona, la va portar a traduir textos dramàtics que es representaven en petits locals de Sitges i Barcelona durant la dècada dels 30. Cocteau, Pellerin, Tristan Bernard o Lenormand són alguns dels escriptors que figuren a la llista d'autors traduïts per la barcelonina.

Amb aquest article volen reivindicar la figura d'una traductora poc coneguda, que desapareix de la vida pública a finals de 1938, després d'una vida compromesa des del punt de vista cultural, intel-lectual i polític. A més, i aquí radica la novetat del present treball, publiquem uns fragments, fins ara desconeguts, que ens han arribat, de les obres que va traduir.

Paraules clau: Maria Carratalà, traducció teatral, teatre de preguerra, companyies amateurs.

Abstract: Maria Carratalà was president of the Lyceum Club in Barcelona, a forum for women with artistic and intellectual interests, between 1933 and 1935. Her friendship with Artur Carbonell, a theatre director and later a professor at the Barcelona Theatre Institute, led her to translate

$\left.{ }^{*}\right)$ Aquest treball s'inscriu en les activitats del Grup d'Estudis de Gènere: Traducció, Literatura, Història i Comunicació (GETLIHC) (20I4, SGR 62) de la Universitat de Vic - Universitat Central de Catalunya i en el projecte I+D+I «Traducción y censura: género e ideología (I939-2000)», amb el número de referència FFI20I452989-C2-2-P, finançat pel Ministerio de Economía y Competitividad. 
dramatic texts that were staged at small venues in Sitges and Barcelona during the I930s. Carratalà translated Cocteau, Pellerin, Tristan Bernard and Lenormand, among other writers.

The aim of this paper is to highlight the figure of a little-known translator, who disappeared from public life at the end of 1938, after a lifetime of cultural, intellectual and political commitment. This study is also the first publication of hitherto unknown extracts from the works she translated.

Key words: Maria Carratalà, theatre translation, pre-war theatre, amateur companies.

$\cos \cos$

\section{ALGUNES DADES BIOGRÀFIQUES}

Quan el diumenge I2 de juny de I938 Maria Carratalà va llegir a La Vanguardia l'anunci de la seva conferència titulada "Contes infantils», programada per a un parell de dies més tard, no sabia ni tampoc s'imaginava que seria l'última vegada que el seu nom sortiria al rotatiu barceloní; un nom que va començar a aparèixer al febrer de I9I4, quan amb només I4 anys ja formava part dels alumnes del Conservatori del Liceu que despuntaven en els concerts escolars públics. Però potser abans d'arribar aquí convindria començar pels orígens, uns orígens que es remunten al is de juny de i899, quan Maria Carratalà Van den Wouver neix a la ciutat de Barcelona.

Va entrar a estudiar a l'Escola Francesa als set anys i als nou ho féu al Conservatori del Liceu, on va cursar la carrera de piano. Distingida compositora i artista, actuà des de ben jove al Conservatori, a la Sala Mozart i a la Sala Aeolian de Barcelona, on compartia sovint cartell amb Pilar Rufí i Concepció Callao. A la primavera de 1920 també va fer una sèrie de concerts a París.

Dona compromesa políticament, el seu nom apareix entre les militants de la Secció Femenina d'Acció Catalana, constituïda l'any 1932, i del Front Únic Femení Esquerrista de Catalunya, del mateix any. També formà part del grup de les fundadores del Lyceum Club de Barcelona, del qual fou presidenta entre 1933 i 1935. En aquesta entitat cultural s'encarregà d'organitzar les vetllades musicals i teatrals des de I93I. També és palesa la seva participació en el Club Femení i d'Esports de Barcelona i en l'Institut de Cultura i Biblioteca Popular de la Dona.

És autora d'una biografia de Pau Casals, en col-laboració amb Joan Llongueras i Josep Ramon: Pau Casals (Barcelona, La Nova Revista, 1927); tres peces teatrals: Florentina, La mort al parapet i El mantó de Manila, de les quals només ha perviscut la primera, editada per Foguet i Boreu (2006); sis traduccions: del francès, Orfeu, 
de Jean Cocteau; Caps de recanvi, de Jean-Victor Pellerin, Antonieta o la tornada del marquès, de Tristand Bernard, publicada per Llibreria Bonavia, Barcelona, I935, i La Innocent, d'Henri-René Lenormand; de l'alemany, Egmont, ${ }^{1}$ de J. Wolfgang Goethe; i Davant la mort, d'August Strindberg, ${ }^{2}$ i més d'un centenar d'articles de creació, de crítica literària i musical, d'opinió política, ressenyes, etc. a diferents publicacions de l'època, com Meridià, La Revista, D'Ací i d'Allà, Mirador, El Matí, La Dona Catalana, per citar-ne algunes.

Entre 1929 i 1938 destaca el seu paper com a conferenciant i, arran de l'esclat de la Guerra Civil, s'intensifica el seu compromís polític i social amb l'esquerra i amb les dones.

El I4 de gener de 1939 publica a Meridià el seu darrer article i desapareix de la vida pública: exili?, presó?, silenci imposat? Són interrogants que encara hem de resoldre. On s'està o s'amaga entre aquesta data i el I8 de febrer de 1950, moment en què dóna una conferència en una de les tertúlies literàries que celebra a casa seva la cantatriu i amiga personal Pilar Rufí? ${ }^{3}$ Són buits de la història que encara s'han d'anar omplint al llarg de la investigació que estem portant a terme. El que és evident és que la seva veu ja no es va tornar a sentir, i les seves amistats, que amb el nou règim es reorganitzaven ideològicament — pensem, per exemple, en el poeta Jorge Juan o el director teatral Artur Carbonell—, la van ignorar i la van deixar de banda, ja que no es van prendre ni la molèstia de renegar públicament d'ella.

La mort li arriba el 2I de març de 1984. Soltera, sense família i malalta, l'Ajuntament de Barcelona la va ingressar a la residència de San Juan de la Salle, avui desapareguda. La unitat geriàtrica municipal es va fer càrrec del seu enterrament al cementiri de Montjuïc. Tres anys després, com que ningú no va reclamar el cadàver i no es pagaven les taxes del nínxol, cosa habitual en els sense sostre, seguint els protocols, les seves restes van anar a parar a una de les fosses comunes del cementiri. Avui dia és impossible saber en quina s'hi troba.

Aquest és el final de Maria Carratalà van den Wouver, traductora, periodista i dona compromesa, no sols silenciada, sinó tornada anònimament a la terra.

I. Com assenyalo més endavant, tinc els meus dubtes sobre si aquesta traducció va ser realment feta per ella en col-laboració amb altres traductors de renom.

2. No he pogut esbrinar si la traducció d'aquesta obra del dramaturg suec procedia del francès o de l'alemany, llengües que Carratalà coneixia perfectament. En qualsevol cas, es va tractar d'una traducció indirecta.

3. Entre I947 i I950, Pilar Rufí organitzà a casa seva, al carrer Muntaner núm. 91, una sèrie de vetllades musicals i literàries. A la llista de les sessions que reprodueix Samsó (I994: 242), trobem que el I8 de febrer de I950 Maria Carratalà pronuncia la conferència «Arte temporal y arte espacial: música y pintura». És l'única conferència que ens consta feta per ella en castellà.

Caplletra 61 (Tardor, 2016), pp. 37-59 


\section{TRAJECTÒRIA TRADUCTOLÒGICA}

Sempre s'ha parlat del caràcter efímer del teatre. Si, a més, aquest és un teatre amateur i es limita a una o dues representacions, aquesta 'efimeritat' es duplica i els textos s'esvaeixen amb molta més facilitat. Per sort, hem aconseguit rescatar alguns fragments de les traduccions que es van publicar al setmanari Baluart de Sitges, i, gràcies a les cròniques aparegudes en diaris i revistes, podem recuperar una part de la història teatral catalana poc o gens coneguda.

De la tasca de Maria Carratalà com a traductora m’agradaria assenyalar quatre punts claus:

a) Es concentra en un període de temps molt concret: 1930-I936, és a dir, fins al començament de la Guerra Civil. ${ }^{4}$

b) Va lligada a un nom: Artur Carbonell, pintor, escenògraf, director de teatre $\mathrm{i}$, anys després de la guerra, catedràtic de l'Institut del Teatre de Barcelona.

c) Se centra en dos espais dramàtics: el Casino Prado Suburense de Sitges i el Teatre Studium de Barcelona. ${ }^{5}$

d) Les obres que tradueix són representades per companyies d'actors aficionats.

Faig aquestes puntualitzacions perquè les traduccions són fetes expressament dins d'aquests paràmetres i no van ser pensades inicialment per ser publicades, si bé una d'elles — Antonieta o la tornada del marquès_ - va ser editada el I935 a Barcelona per la Llibreria Bonavia. Sembla també que López Picó tenia la intenció de publicar la traducció d'Orfeu de Carratalà a La Revista, però finalment no va veure la llum per raons que desconeixem. ${ }^{6}$

4. Sobre la situació del teatre amateur durant la Guerra Civil, pot consultar-se l'article de Foguet i Boreu (1998b).

5. El Casino Prado Suburense està situat al carrer Francesc Gumà núm. 6 de Sitges i va néixer el I877 com una societat recreativa per fer activitats culturals i lúdiques. El Teatre Studium de Barcelona, conegut inicialment com el Taller-estudi Masriera, es troba al carrer Bailén núm. 6. És un edifici en forma de temple clàssic que acollia pintors i escultors i on representava la companyia Belluguet, creada el I92I per Lluís Masriera i Roses. L'any I932 aquest espai es transformà en el Teatre Studium, i és en aquest local on el Lyceum Club de Barcelona programava anualment, entre 1934 i I936, una vetllada teatral de caire elitista on es representaven les millors obres de teatre internacional contemporani no estrenades mai a casa nostra. Aviat aquestes representacions es convertirien en un referent per a les companyies amateurs i un punt de trobada per a la intel-lectualitat barcelonina.

6. A l'entrada «Carratalà, Maria» de l'Enciclopèdia Espasa-Calpe (edició de 1930) es pot llegir, entre altres informacions, la següent: «Ha traducido el poema (sic) Orfeu, de Cocteau, obra estrenada en Sitges en septiembre de 1930 y que próximamente se publicará en La Revista, de López Picó». 
Com acabo d'assenyalar, és de la mà d'Artur Carbonell que Carratalà s'introdueix al món del teatre i de la traducció. No queda prou clar si la selecció de les obres que tradueix la fa ella personalment, amb l'acord de Carbonell, o si són directament un encàrrec d'ell. ${ }^{7}$ El que sí que podem afirmar és que les primeres peces que gira al català són obres que ell ha vist estrenades a París o de les quals ha sentit parlar al cercle d'Amics de les Arts, del qual formava part (Gallén 20I2: 40). Totes elles són innovadores, modernes, avantguardistes — en molts casos— $\mathrm{i}$ aniran acompanyades de la polèmica.

I la vàlua de la tasca de Maria Carratalà resideix en el fet que no hi havia cap traducció al català (i en alguns casos tampoc al castellà, val a dir-ho) dels textos que Carbonell posa en escena. ${ }^{8}$ Ella coneixia bé el francès — havia estudiat a l'Escola francesa de Barcelona, havia estat a París i la seva mare era nascuda a la capital francesa. Així, d'aquesta manera tan casual i sense pretendre-ho, perquè la seva professió era la de concertista de piano, es converteix en la primera traductora al català (i de vegades l'única) de Cocteau, Pellerin, potser Goethe — ja en parlarem més endavant—, Bernard, Strindberg i Lenormand.

Reconstruir la trajectòria traductològica de Maria Carratalà no ha estat una tasca senzilla i la cerca dels textos íntegres ha estat infructuosa — malgrat l'esforç i la remenada de documentació teatral i colllateral—, però hem aconseguit rescatar alguns fragments desconeguts de les traduccions de les representacions que es van muntar al Prado Suburense i algunes fotografies de les representacions que es van fer al Teatre Studium. ${ }^{9}$

7. Segons Foguet i Boreu, era ella qui s'encarregava directament de la selecció de les peces: «La tria de les obres era responsabilitat, en concret, de l'escriptora Maria Carratalà, dirigent destacadíssima de l'entitat cultural femenina i directora literària del seu [del de Carbonell] grup amateur» (1998a: 62). És del tot cert que ella s'encarregava de dirigir les vetllades teatral i musical del Lyceum Club, però la manca de dades sobre la seva relació personal amb Carbonell ens impedeix admetre taxativament l'afirmació de Foguet, especialment pel que fa a les peces representades al Casino Prado Suburense.

8. La primera traducció d'Orphée de Jean Cocteau al castellà fou feta per Corpus Barga el I925 i fou publicada per la Revista de Occidente l'any 1927. Aquesta traducció serví per al muntatge que va fer Cipriano Rivas Cherif a la Sala Caracol de Madrid el 1928 (Gallén 20I2: 43, n. 4); en català no n’hi ha cap versió. Têtes de rechange no coneix cap versió ni en castellà ni en català. De l'Egmont hi ha la traducció que Ramon Maria Tenreiro va preparar l'any 1929 per a l'editorial Espasa-Calpe i una versió en català editada per la Institució del Teatre de la Generalitat de Catalunya, de Joaquim Pena, de l'any 1937, per tant, posterior a la de Carratalà. D'Antonieta o la trobada d'un marquès no he trobat cap versió ni catalana ni castellana publicada. Al Fons Artur Carbonell de l'Arxiu Municipal de Sitges (a partir d'ara, AMS) trobem el manuscrit de la versió espanyola de l'obra que va ser muntada el 1948 pel mateix Carbonell al Casino Prado Suburense. Davant la mort de Strindberg no compta amb cap traducció al català, però sí al castellà (Ante la muerte), obra d'Alejandro Rodríguez Álvarez per a l'editorial Mundo Latino de Madrid, 1929. La Innocent no coneix cap versió al català; la primera al castellà data de 1943 i fou feta per Alejandro Casona per a l'editorial Losada de Buenos Aires.

9. Gran part del material d'aquest treball procedeix del Fons Artur Carbonell (AMS); vull donar les gràcies al seu arxiver, Xavier Miret i Mestre, per la seva amabilitat i diligència. 
Les obres que Maria Carratalà tradueix són les següents:

1930. Orfeu, de Jean Cocteau (Casino Prado Suburense, Sitges)

1931. Caps de recanvi, de Jean-Victor Pellerin (Casino Prado Suburense, Sitges)

1932. Egmont, de J. W. Goethe. En colllaboració amb Marià Manent, Jaume Bofill i Ferro, Anna Maria de Saavedra i Carles Riba (Casino Prado Suburense, Sitges)

1934. Antonieta o la tornada del marquès: Sainet en un acte, de Tristan Bernard (Teatre Studium, Barcelona)

1936. Davant la mort, d'August Strindberg (Teatre Studium, Barcelona)

1936. La innocent, d'Henri-René Lenormand (Teatre Studium, Barcelona)

\section{LES TRADUCCIONS TEATRALS}

\section{Orfeu, de Jean Cocteau (1930)}

L'i de setembre de 1930, Artur Carbonell s'estrena com a director teatral i representa al Casino Prado Suburense de Sitges l'Orfeu, de Cocteau, amb el seu grup de teatre amateur. La traducció catalana és a càrrec de Maria Carratalà, que ja tenia enllestida la feina el dia to de juliol, segons comunica al seu amic Manuel de Blancafort en carta datada el 2I de juliol de 1930. I sobre el procés de la traducció li confessa: «Enriguisse'n de la facilitat». ${ }^{10}$

Gràcies a les cròniques d'alguns periodistes sitgetans, sensibles al món de la traducció, ens han arribat valoracions sobre la feina de la traductora: «Maria Carratalà n'ha fet una excel-lent traducció expressament per aquesta representació» (anònim); «Fem notar, també, la gentilesa de Maria Carratalà en traduir Orfeu expressament per la vetllada de demà, i de donar-nos-el en un català madur i exquisit» (Ramon Planes); «Traduïda per la senyoreta Maria Carratalà amb la perícia a què aquesta jove escriptora ens té habituats» (anònim); «La traducció, feta per la distingida literata Maria Carratalà, excel-lent» (anònim). ${ }^{11}$ I Salvador Marsal afirmava:

Io. Llegat Manuel Blancafort, Cartes, Biblioteca de Catalunya (M. 4896/I).

II. Les cròniques periodístiques poques vegades van signades; normalment, o no apareix el nom del redactor o simplement són inicials. M’han estat molt útils des del punt de vista documental els retalls de premsa del Fons Carbonell (AMS), ja que Carbonell guardava tots els anuncis, cròniques i crítiques de les obres que 
Maria Carratalà n'és l'autor (sic) de la versió catalana d'Orfeu. La seva tasca, que coneixem detalladament, és d'una exactitud i d'una precisió admirables. No en el sentit de la fidelitat de la traducció, que hauria perjudicat l'adaptació catalana, sinó en la visió finament observada de la veritable valor de l'obra. El llenguatge emprat per Maria Carratalà contribueix, doncs, a ressaltar la teatralitat d'Orfeu.

\section{De la traducció que va fer la barcelonina tenim un tast, l'escena final, publicat al Baluart de Sitges (Cocteau 1927: I25-I26): ${ }^{12}$}

\section{Escena final de la tragèdia ORFEU, de Jean Cocteau, traduiida per Maria Carratalà}

La decoració puja al cel. Entren pel mirall: Eurídice i Orfeu, Topacerç els mena. Miren la casa com si la veiessin per primera vegada. S'asseuen a taula. Eurídice indica la seva dreta a Topacerç. Tots somriuen. Respiren la calma més perfecta.

EURÍDICE. Oi que volies vi, estimat?

ORFEU. Espera, primer l'Oració. (S'alça. Eurídice i Topacerç s'alcen també. Orfeu recita). Déu meu, us donem gràcies per haver-nos assenyalat la nostra casa i el nostre matrimoni com a únic paradís. Us donem gràcies per haver-nos enviat Topacerç i ens acusem de no haver reconegut el nostre àngel de la guarda. Us donem gràcies per haver salvat Eurídice que, per amor, occí el diable en forma de cavall i va morir-ne. Us donem gràcies per haver-me salvat a mi que adorava la poesia, però la poesia sou Vos. Així sia. (Asseuen)

TOPACERÇ. Serveixo?

ORFEU. (Respectuosament) Deixeu a Eurídice... (Eurídice li posa vi)

TOPACERÇ. Potser sí que arribarem a dinar...!

TELÓ

\section{SCÈNE XIII}

Le décor monte au ciel. Entrent par la glace: Eurydice et Orphée. Heurtebise les mène. Ils regardent leur maison comme s’ils la voyaient pour la première fois. Ils s'asseyent à table. Eurydice désigne sa droite à Heurtebise. Ils sourient. Ils respirent le calme.

EURYDICE. Tu voulais du vin, je crois, mon chéri.

ORPHÉE. Attends. D'abord la prière. (Il se lève ainsi qu'Eurydice et Heurtebise. Il récite). Mon Dieu, nous vous remercions de nous avoir assigné notre demeure et notre ménage comme seul paradis et de nous avoir ouvert votre paradis. Nous vous remercions de nous avoir envoyé Heurtebise et nous nous accusons de n'avoir pas reconnu notre ange gardien. Nous vous remercions d'avoir sauvé Eurydice parce que, par amour, ell a tué le diable sous la forme d'un cheval qu'elle en est morte. Nous vous remercions de m'avoir sauvé parce que j'adorais la poésie et que la poésie c'est vous. Ainsi soit-il. (Ils se rasseyent).

representava. Va descuidar, en canvi, indicar-hi el nom del diari d'on s'havia extret la notícia i la data. En alguns casos he pogut reconstruir aquesta informació (i l'he proporcionada); en d'altres, no ha estat possible.

I2. Reprodueixo aquí el fragment traduït que es va publicar, i a continuació el fragment corresponent de la versió original. Seguiré el mateix procediment en totes les traduccions. 
HEURTEBISE. Je vous sers?

ORPHÉE (Respectueusement). Laissez Eurydice... (Eurydice lui verse à boire).

HEURTEBISE. Peut-être arriverons-nous enfin à déjeuner.

RIDEAU

Si analitzem la traducció al català, de seguida ens adonem de la naturalitat dels diàlegs, dels girs nostrats i de la plasticitat del llenguatge dramàtic que aconsegueix imprimir Carratalà al text traduït, un text que manté plena vigència malgrat els vuitanta-tres anys d'ençà que fou traduït.

Sobre què va passar la nit de l'estrena ens han arribat diverses informacions. Davant d'un nombrós i selecte públic es representa aquest Orfeu, obra polèmica de caire avantguardista que si va irritar a la seva estrena a París, no havia de deixar indiferents els sitgetans. "¿Teníamos que ser menos nosotros? », afirmava Carbonell (I956) a la conferència que va fer a l'Institut del Teatre l'any 1956 sobre la seva experiència artística.

Segons la crítica, l'obra tingué defensors i detractors, i juntament amb els aplaudiments se sentiren els xiulets d'un grup d'afeccionats al teatre que no entenia el que s'estava representant, i que no era altra cosa que la revisió dels clàssics en clau contemporània: «L'obra, ja es pot suposar, és d'un gran avantguardisme: personatges mitològics amb suèter, escenes desconcertants, frases explosives, conceptes desorbitats, situacions originalíssimes, ambient de tragèdia, de vodevil, de somni, de poema fantàstic...» (J. S., Mirador, núm. 84, 4-9-1930).

I aprofitem part del relat que oferia J. S., que va viure de primera mà l'espectacle i resumeix el que es va esdevenir a dalt l'escenari (Mirador, núm. 84, 4-9-1930):

Un cavall de cartó diu el mot de Cambronne, que Orfeu repeteix lletra per lletra al dictat de les guitzes del cavall; un espill que fa de passadís entre l'Olimp i el menjador d'una família burgesa; un cap tallat que rodola per l'escena i després parla convertit en bust d'Orfeu; Orfeu amb suèter i pantalons de golf; Eurídice vestida d'estar per Sitges; el vidrier, futur Àngel de la Guarda; la Mort vestida de «soirée» per a disfressar-se immediatament de llevadora, dos practicants de metge que ajuden la Mort tan bé com poden.

Un tal VIRUS, a «Tallant abusos», escrigué una àcida columna sobre l'obra, que provocà tota una sèrie de rèpliques al diari, i diu (La Punta):

El concepte que ens mereix aquesta imbecilitat i poca solta d'obra és tan agre que la nostra ploma no pot ni vol escriure'l. Hem de creure que Cocteau haurà escrit aquesta estupidesa amb els peus en lloc de fer-ho amb el cap i sentiment.

Val a dir que el crític arremet contra l'autor i l'obra, però no diu res de la traducció o de l'actuació del grup amateur que va executar la peça —-magníficament, per cert, a judici dels periodistes - i que estava format per Maria Dolors Bertran (Eurídice), 
Teresa Julio

Recuperant la memòria històrica: Maria Carratalà, una traductora teatral de preguerra

Maria Planas (la Mort), Darna i Artur Carbonell (metges); Josep Mirabent (Orfeu), Pere Armengou (vidrier), Daniel Planas (policia) i Josep Maria Bassols (escrivent). Els mateixos actors es van encarregar de fer els decorats i representar l'obra seguint les pautes marcades pel mateix Cocteau: «La obra estaba ensayada a conciencia siguiendo al pie de la letra las instrucciones dadas por el autor. El decorado pintado por nosotros mismos era fiel complemento de la obra» (Carbonell 1956).

\section{Caps de recanvi, de Jean-Victor Pellerin (193I)}

Si exitosa i polèmica havia estat la representació de l'Orfeu, l'expectació que va causar Caps de recanvi, de Jean-Victor Pellerin, l'any següent no es va quedar enrere (C. M., Mirador, núm. 137, I7-9-1931):

Tant per la novetat de l'argument, com per l'enginy de la trama, l'atreviment del diàleg i la modernitat del desenrotllament, Caps de recanvi presenta grans dificultats, no sols per als distingits artistes aficionats que ardidament se n’emprengueren la representació sinó per els espectadors que acudiren a fruir-ne, que es pot dir que hi anà tot Sitges en pes, de tal manera que el Prado presentava l'aspecte del Liceu barceloní en dia de solemnitat.

Una altra vegada la traducció del text francès recau en Maria Carratalà i la direcció artística de l'espectacle, en Artur Carbonell. L'espai escènic, el mateix: el Casino Prado Suburense de Sitges; i l'estrena, el Io de setembre de I93I.

El quadre d'actors que va executar aquesta complicada peça de Pellerin estava format per Josep Mirabent (Ics), Daniel Planes (Opecú), Maria Glòria Muntanyola (una Cecília i una dependenta), Concepció Jacas de Bassols (la pagesa i una esportiva), Maria Dolors Bertran (la noia mundana i una núvia), Pura Almendros de Duran (la modisteta), Josefina Planes (l'obrera), Ricard Roig (capellaire i home sandwitx), Josep M. Bassols, Pere Armengou, Ferran Bassols (el padrí i un burgès), el nen Claudi Bassols (el seu fill), Bonaventura Blai, Joan Ferrater i Artur Carbonell (el jove mundà).

La traducció de la barcelonina va ser comentada a diverses publicacions: «Orfeo de Jean Cocteau i l'altre Caps de recanvi, ambdues obres traduïdes pulcrament per Maria Carratalà [...] El llenguatge és concís, depuradíssim i dóna la sensació que Maria Carratalà, ultra ésser fidel a la peça de Pellerin, ha assolit de transportar-la al català sense pèrdua de tensor i amb un tracte poc usual entre els traductors» (S. Soler i Forment ); «[...] Finalment, esmentem l'acurada traducció de Maria Carratalà» (X. El Matì); «Escrita en un francès d'alta qualitat, ha estat traduïda en un català depuradíssim per Maria Carratalà, al punt de no fer-vos enyorar gens el text original» (Baluart de Sitges). I aquest mateix diari, el Baluart de Sitges, publicava el 6 de setembre de I93I el fragment següent: 


\section{Fragment de l'obra, primera part (traduït per Maria Carratalà)}

ICS. Mira, un exemple entre tants: el teu viatge sí, no més tard que avui; del fons dels Pirineus fins aquí. Què era per tu aquest viatge? Un lleure ric de possibilitats i de sorpreses. I tu què n'has fet, veiam?

OPECÚ. I els diaris que he comprat a l'estació, les revistes gràfiques...

ICS. Sí, tot el que necessitaves per ensopir-te.

OPECÚ. I bé, què vols que faci en un vagó?

ICS. Que hi havia, en aquest vagó? Anava buit?

OPECÚ. Ja pots pensar que he fet per manera d'estar sol.

ICS. Viatjaves en primera, és clar! I no miraves mai per la portella?

OPECÚ. Ja saps que a mi el paisatge...

ICS. No era habitat, aquest paisatge?

OPECÚ. Sí que era habitat.

ICS. Així, digues, que tu en tot el trajecte no t'has interessat... — per qui et diré jo? - per la família d'un guarda agulles, per uns mossos que batien a l'era d'una masia, per unes dones que rentaven en un riu, per un capellà que passava per la carretera.

$\mathrm{Ni}$ has tingut la curiositat d'entrar en un d'aquells pisets que es veuen, en els suburbis, amb la roba del llit penjant per la finestra oberta.

OPECÚ. Però si el tren no para?

ICS. Ah! Si jo hagués estat al teu lloc...! La conec aquesta línia, t’asseguro que... Mira, no gaire lluny de París, el tren passa per propietats d'unes famílies nobles que encara viuen al vell casal dels avis. Són uns terrenys poblats d'arbres corpulents, les branques inclinades fan de sostre a uns caminets plens d'ombra... Som a l'abril... Les fulles tenen un verd lluent... Els vestits clars d'unes noies destaquen damunt l'herba... Són unes noies d'abans... sempre se'n troben algunes d'aquestes noies. N'hi ha una que se separa de les altres... Camina a passes menudes... Esvelta i lànguida. Rossa — no podia ser d'altra manera — i delicadament rosada... Ve cap aquí... Mira-la.

\section{TÊTES DE RECHANGE}

IXE. Exemple entre mille: ton voyage, —oui, pas plus tard qu'aujourd'hui, depuis le fin fond des Pyrénées jusqu'ici. Que s'offrait-il d'être por toi ? Un loisir, gros de possibilités, riche en surprises peut-être. Qu'en as-tu fait?

OPÉKU. Eh bien, mais... les journaux, quelques illustrés, la Revue des Deux Mondes...

IXE. Tout ce qu'il faut pour dormir.

OPÉKU (Agacé). Ha ! que veux-tu qu'on fasse dans un wagon?

IXE. Il était vide?

OPÉKU. Tu penses bien que je m’étais arrangé pour être seul dans mon compartiment.

IXE. O premières classes !... Et dehors? Le long des voies ? Tu ne regardes jamais par la portière? OPÉKU. Moi, tu sais, les paysages...

IXE. Ils sont habités.

OPÉKU. Habités ?... Lentement, le levier se met en marche et regagne la position Loisir.

IXE (Qui s'exalte peu à peu). Ainsi, durant tout ce trajet, pas une fois tu n'as daigné faire connaissance avec... que sais-je ?... avec une famille de garde-barrière... une cour de ferme... une ville de banlieue... un curé à bicyclette ?... Tu n'as même pas eu la curiosité de pénétrer dans ces petits logements des faubourgs qui laissent pendre leurs lits défaits par une fenêtre ouverte? 
OPÉKU. Mais le train ne s'arrête pas.

IXE. Est-ce une raison pour ne pas t'arrêter?

OPÉKU (Très digne). Mon cher neveu...

IXE. Ah ! si j'avais été à ta place !... Je la connais, cette ligne-là, et je t'assure que... Tiens ! à un moment, pas très loin de Paris, juste après une longue plaine morne, le train coupe en deux quelques vieilles propriétés aux châteaux désuets, aux grands arbres massifs penchés sur des allées d'ombre que l'herbe envahit... Nous sommes en avril... les verdures étalent un vert tout neuf qui luit au soleil et qui sent bon... Il y a sur la pelouse des robes claires de jeunes filles... de jeunes filles d'autrefois... Il y a toujours des jeunes filles d'autrefois... L'une d'elles se détache du groupe... Il y en a toujours une qui se détache... Elle marche à petits pas... Sveltesse et langueur, blond sans aucun doute et rose... Elle approche... La voici.

(Pellerin I929: I2I-I23)

La traducció de Carratalà és àgil, fresca i, com a traductora, pren decisions per tal de no crear un text estrangeritzant: per exemple, omet el títol de la revista francesa Revue des Deux Mondes, totalment desconeguda a Espanya; o el que es veu per la finestra del tren no és «une cour de ferme... une ville de banlieue», sinó «uns mossos que batien a l'era d'una masia, [...] unes dones que rentaven en un riu»); abreuja algunes intervencions i dóna un aire de naturalitat a la conversa per tal de crear un diàleg ple de vitalitat.

\section{Egmont, de Goethe (1932)}

L'any següent, el 1932, se celebra el centenari de la mort de Goethe. Es forma el Comitè Gestor del Centenari de Goethe a Catalunya, presidit per Ángel Valbuena Prat, que pren l'acord de nomenar l'Artur Carbonell el seu mandatari a Sitges. ${ }^{13}$ Entre els actes que proposa el Comitè, un és fer "possiblement una adaptació d'Egmont, a càrrec d'estudiants i a cura d'una direcció facultativa»; i hem de suposar que la direcció facultativa devia estar formada per Marià Manent, Jaume Bofill i Ferro, Anna Maria de Saavedra, Maria Carratalà i Carles Riba, ja que són aquests els noms dels traductors que han passat a la història, encara que, pels defectes de la traducció — si hem de fer cas al cronista de torn i hem de jutjar el fragment que ens n'ha arribat-, difícilment ho podrien ser, per bé que Carbonell (1956) en fa alguna referència a la categoria dels traductors: «De la Universidad de Barcelona recibo el nombramiento

I3. La carta d'Ángel Valbuena Prat a Artur Carbonell, datada el 23 de febrer de 1932, es troba al Fons Artur Carbonell (AMS). El Comitè del Centenari de Goethe a Sitges estava integrat per Josep Planas i Robert (president), Carolina Benaprès (secretària), Josep Carbonell i Gené, M. Cassanyes, Joaquim Gomis, Alfons Macaya i Salvador Soler i Forment.

Caplletra 61 (Tardor, 2016), pp. 37-59 
de mandatario de Sitges, en la conmemoración del centenario de Goethe y presento Egmont en una versión anónima que oculta los nombres de los más prestigiosos poetas, y con un montaje completamente inédito».

Abans de l'estrena es va produir una anècdota que no em resisteixo a transcriure. Ens la proporciona la revista Mirador (núm. I88, 8-9-1932), a propòsit de la representació que es farà a Sitges de l'Egmont:

Els organitzadors del festival — que serà en homenatge al geni de Weimar-anaren a oferir un dels papers femenins de l'obra a una distingida dama de la "colònia», la senyora M., la qual va contestar-les:

—No vull prendre part en la interpretació d'Egmont perquè no vull representar obres comunistes. -Però, senyora, si és una traducció de l'obra, de Goethe...

-Bé, sí, tot el que vulgueu. La traducció pot ésser feta amb tendències comunistes.

Els organitzadors, davant la insistència de la dama, van acordar obrir una informació per a comprovar si en el cos de traductors s'hi havia infiltrat algun deixeble de Lenin.

\section{L'II de setembre de I932 el Baluart de Sitges publicà el fragment següent:}

\section{CASA DE CLARA}

CLARA. (Surt de la cambra amb una llàntia $i$ un vas d'aigua: posa el vas damunt la taula $i$ s'atansa a la finestra). Sou vos, Brackenburg...? Què era, doncs, el que he sentit? No ve ningú encara? No, ningú...! Posaré la llàntia a la finestra perquè vegi que estic desperta, que encara l'espero. Va prometre'm que em duria noves. Noves? Espantosa certesa! Egmont sentenciat! A quin tribunal li serà lícit fer-lo comparèixer? I el condemnen! Qui el condemna: el rei? El duc? I la governadora es retira. Orange vacil.la i també els seus amics... és aquest el món inconstant i infidel de què tant m’han parlat i que jo no coneixia? És així, el món? Qui seria prou pervers per sentir odi contra el millor dels homes? És que la malícia seria prou poderosa per abatre en un instant el qui tots veneren...? Oh, Egmont! I jo que et creia tan segur davant de Déu i dels homes, com quan et tenia als braços! I què era jo per tu? Em vas dir «teva» i vaig consagrar a la teva vida tota la meva vida... Que sóc jo ara? En va allargo les mans cap a la xarxa que et té pres. Tu, indefens, i jo lliure...! Tinc la clau de la meva porta. Entrar i sortir depèn només del meu voler, i de res no puc servir-te... Oh, lligueu-me, perquè no em desesperi; llenceu-me a la presó més pregona, perquè em pugui colpir el front contra els meus murs humits, i gemegui la llibertat, i somniï la manera d'alliberar-lo si no em lliguessin cadenes!... Ara estic lliure i en la llibertat sento l'angoixa de la meva feblesa... prou sé que no [sóc] capaç no de donar un pas per ajudar-lo. Ai, per dissort teva, també aquesta petita part del teu ésser que es diu Clara és, com tu, presonera, i lluny de tu se sent morir d'angoixa! Sento que algú s'avança amb cautela... Brackenburg... Sí, és ell...! Home bo i dissortat, la teva sort sempre és igual; la teva amada t’obre la porta nocturna, però, ai!, és només per una cita siniestra.

Entra Back.

CLARA. Vens pàl-lid i tremolós, Brackenburg! Què passa?

BRACK. He vingut a trobar-te fent llargues marrades i a través de perills. Els carrers principals són plens de tropa; d'amagat he arribat fins a tu, esmunyint-me per carrerons tortuosos. 


\begin{abstract}
Alärchens Haus
Alärchen kommt mit einer Lampe und einem Glas Wasser aus der Kammer, sie setzt das Glas auf den Tisch und tritt ans Fenster.

Alärchen. Brackenburg? Seid Ihr's? Was hört'ich denn? Noch niemand? Es war niemand! Ich will die Lampe ins Fenster setzen, daß er sieht, ich wache noch, ich warte noch auf ihn. Er hat mir Nachricht versprochen, Nachricht! entsetzliche Gewißheit! —Egmont verurteilt! —Welch Gericht darf ihn fordern? Und sie verdammen ihn! Der König verdammt ihn? oder der Herzog? Und die Regentin entzieht sich! Dranien zaudert und alle seine Freunde! — — Ist dies die Welt, von deren Wankelmut, Unzuverlässlichkeit ich viel gehört und nichts empfunden? Ist dies die Welt? - Wer wäre bös genug, den Teuren anzufeinden? Wäre Bosheit mächtig genug, den allgemein Erkannten schnell zu stürzen? Doch ist es so — es ist! O Egmont, sicher hielt ich dich vor Gott und Menschen, wie in meinen Armen! Was war ich dir? Du hast mich dein genannt, mein ganzes Leben widmet'ich deinem Leben. - Was bin ich nun? Vergebens streck'ich nach der Schlinge, die dich faßt, die Hand aus. Du hilflos, und ich frei! — Hier ist der Schlüssel zu meiner Türe. An meiner Willkür hängt mein Gehen und mein Kommen, und dir bin ich zu nichts! - — O, bindet mich, damit ich nicht verzweifle, und werft mich in den tiefsten Kerker, da $\beta$ ich das Haupt an feuchte Mauern schlage, nach Freiheit winsle, träume, wie ich ihm helfen wüsste, wenn Fesseln mich nicht Iähmten, wie ich ihm helfen würde. —Nun bin ich frei! Und in der Freiheit liegt die Angst der Ohnmacht. —-Mir selbst bewußt, nicht fähig, ein Glied nach seiner Hilfe zu rühren. Ach, leider, auch der kleine Teil von deinem Wesen, dein Alärchen, ist wie du gefangen und regt getrennt im Todeskrampfe nur die letzen Kräfte. - Ich höre schleichen, husten — Brackenburg — er ist's! — Glender Elender guter Mann, dein Schicksal bleibt sich immer gleich: dein Liebchen öffnet dir die nächtliche Türe, und ach zu welch unseliger Zusammenkunft.
\end{abstract}

Brackenburg tritt ein.

Alärchen. Du kommst so bleich und schüchtern, Brackenburg, was ist's?

Bradenburg. Durch Umwege und Gefahren such'ich dich auf. Die großen Straßen sind besetzt, durch Gäßchen und durch Winkel hab’ich mich zu dir gestohlen.

(Goethe I94I: 73-74)

El repartiment de l'obra va ser el següent: Rosa Montiel (Margarida de Parma), Joan Ferrater (Maquiavel), Maria Dolors Bertran (Clara), Teresa Casanelles (la mare de Clara), Daniel Planas (Brackenburg), Josep Mirabent (Egmont), Pere Armengou (Guillem d'Orange), Ricard Roig (el duc d'Alba), Manuel Muntanyola (Ferran), Sílvia i Gómez (servidors d'Alba).

Gràcies als cronistes locals, que no van quedar gaire contents amb la versió que es va oferir, ens han arribat informacions sobre el que es va posar en escena aquella nit i ens crida l'atenció les seves opinions sobre la traducció. En destaquem la de l'articulista Ramon Planes, que afirmava (Baluart de Sitges, I4-9-1932):

Essent l'adaptació dividida en nou escenes, el muntatge de cada una d'elles s'allargava excessivament, i això va cansar el públic en gran manera. Els descansos tan llargs feien ressaltar un dels pitjors defectes que té el teatre. 
En quant a la traducció, oficialment anònima, ens sembla molt desigual. Potser ho feia la major realitat que té el personatge, però ens féu l'efecte que la part de Clara era força superior, literàriament, a la dels altres herois. Algun passatge feia mal a l'oïda, i en un parlament d'un actor sentirem tres vegades el mot 'sigut'.

Tot plegat, però, quedà salvat per la direcció i per la interpretació.

\section{Sobre la versió representada, Salvador Marsal publica una dura crítica a la revista Mirador (22-9-1932), on diu:}

L'Egmont representat dijous passat a Sitges tenia caràcters d'estrena, puix que era la primera vegada que aquesta traducció — més ben dit, aquesta versió- prenia estructura teatral [...] Però, amb tot, Egmont conté una valor qualitativa prou considerable perquè hàgim d'aplaudir i rebre amb plaer la seva incorporació al nostre idioma.

En arribar a aquest punt, però, ens pertoca parlar una mica de la versió d'Egmont que ens fou oferta i remarcar les reserves pertinents. La versió d'Egmont que fou representada — puix que no pot parlar-se de traducció — fou facilitada oficialment pel Comitè Gestor del Centenari de Goethe a Catalunya. Això constitueix ja una hàbil apel-lació a l'anonimat. Se'ns diu, però, de font autoritzada, que la versió o refosa de l'obra de Goethe pot atribuir-se a la ploma d'Anna Maria de Saavedra, Maria Carratalà, Marià Manent, J. Bofill i Ferro, i Borrás-Prim. ${ }^{14}$ El prestigi i la solvència d'alguns d'aquests noms ens permeten dubtar sobre la part de paternitat d'Egmont que veié la llum primera a Sitges. En aquest, els cinc actes de l'original resten reduïts a tres, els tretze quadres a nou i els vint personatges a onze.

La decapitació de totes les escenes on tenen intervenció soldats, artesans i gent del poble contribueix considerablement a restar uniformitat a l'obra i, altrament, fa desaparèixer del tot la força ambiental que ajuda a formar i comprendre la figura d'Egmont i lleva bona part d'espectacularitat a la tragèdia.

La fúria iconoclasta no es detura, però, en la destrucció dels elements que hem esmentat, sinó que actua també damunt la construcció literària de l'obra. A força de reduir les seves dimensions, el diàleg resta gairebé limitat a una simple i eixuta exposició de fets en detriment de la seva valor psicològica. El llenguatge esdevé cantellut, monòton i mancat totalment de poesia, cosa que perjudica sensiblement l'exacta comprensió del personatge d'Egmont, que esdevé en alguns moments, a causa d'aquestes limitacions, exempt de la grandesa i de la força que li injectà el seu autor.

D'altra banda, el text que ha estat emprat per a representar l'obra conté una sèrie de castellanismes imperdonables.

I4. Aquests noms no coincideixen exactament amb els d'altres fonts més fiables. 


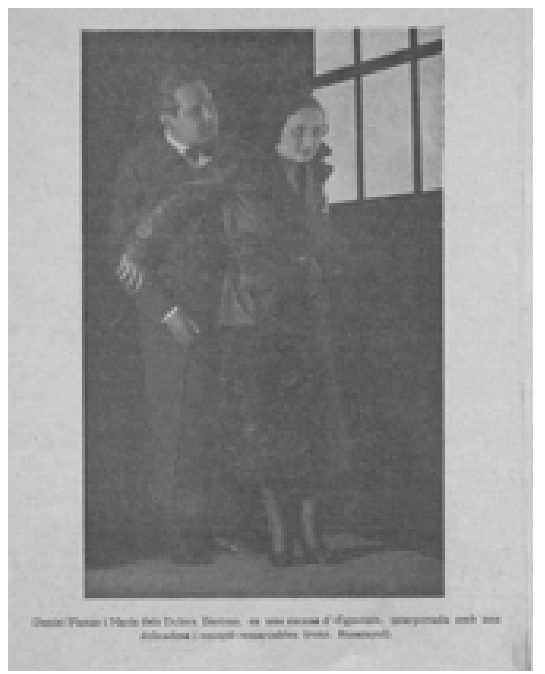

Escena d'Egmont (Fons Artur Carbonell, AMS).

Des del punt de vista argumental, potser la tria de l'obra no va ser del tot casual. Egmont representa la lluita de la llibertat contra l'opressió exterior. El protagonista és un dels prínceps de Flandes que aspira a alliberar el seu poble, dominat pel rei d'Espanya. Aquest paral-lelisme entre els Països Baixos de mitjan segle Xvi i la Catalunya de 1932 va encendre els ànims d'un dels presents a la representació, que en un entreacte va aprofitar l'avinentesa per anar contra l'Estatut que s'havia aprovat una setmana abans (el 7 de setembre de 1932), després d'una depuració històrica d'articles. ${ }^{15}$ Salvador Marsal ens relata l'anècdota següent (Mirador, 22-9-1932):

En un entreacte de l'obra, el senyor Francesc Pujols — a qui no cal presentar- pronuncià un petit parlament al-lusiu a l'acte que es celebrava. Heus ací el que digué Francesc Pujols:

«Tal com heu vist i anireu veient, ara que es parla tant de la llibertat dels pobles, en Egmont també es planteja un cas d'aquests. Els flamencs es volien lliberar de la tirania del duc d'Alba i de la del rei d'Espanya. Això, naturalment, els portava molta feina i nosaltres potser els haurem anat a ajudar si no fos la qüestió de l'Estatut i la feina que ens dóna. Però ara que hi som i no portem pressa (era la una tocada i mancaven encara dos actes i un total de sis quadres) us parlaré de l'Estatut i us diré que jo encara el trobo excessiu, perquè el voldria ben petit, ben migrat i ben esquifit, perquè això ens permetria anar intervenint en el Govern d'Espanya. Nosaltres, sis catalans, no les volem les llibertats de Catalunya. El que volem és

15. L'Estatut que es va aprovar el 9 de setembre de 1932 tenia el seu origen en l'Estatut de Núria, sotmès a plebiscit el 2 d'agost de I93I. Aquest projecte de Francesc Macià es va discutir a les Corts al maig de 1932 i va ser aprovat al setembre després d'una sèrie d'esmenes que va reduir els 52 articles inicials a I8. 
exercir l'hegemonia, la supremacia i el domini damunt d'Espanya, és a dir, el que representa l'imperialisme ibèric d'en Prat de la Riba.»

El públic no acabà d'entendre ben bé la relació que podia haver-hi entre Goethe i l'Estatut, però no s'hi capficà gaire i aplaudí de bon grat.

4. Antonieta o la tornada del marquès, de Tristand Bernard (1934)

El 17 de gener de 1934 es representa al Teatre Studium de Barcelona també sota la direcció d'Artur Carbonell Antonieta o la tornada del marquès. La representació s'emmarca dins dels actes que organitzava el Lyceum Club de Barcelona, presidit llavors per Maria Carratalà. En el mateix acte es van executar tres peces: Un caprici, d'Alfred de Musset; Antonieta o la tornada del marquès, de Tristan Bernard, i Com ell va enganyar el marit d'ella, de Bernard Shaw, traduïdes al català per Rossend Llates, Maria Carratalà i Carles Soldevila, respectivament.

Antonieta és un sainet en un acte poc conegut, que els organitzadors van triar per donar-lo a conèixer al públic. ${ }^{16} \mathrm{~A}$ propòsit de la traducció, els periodistes van elogiar la tasca de la barcelonina: "Traduïda amb agilitat per Maria Carratalà, és una aguda sàtira de la manera com certs aficionats interpreten les comèdies i àdhuc el per què els agrada representar-les» (Domènec Guansé, La Publicitat, I9-I-I934); «La traducción de Maria Carratalá es desenfadada y natural: única solución para esta clase de espectáculo, donde todo pasa en el patio de butacas, subrayando con la palabra lo que la mímica de los actores hacían elocuentemente mudo» (Félix Ros, La Vanguardia, I9-I-I934).

La interpretació — excel.lent, segons els cronistes — va ser a càrrec de Maria Lluïsa Queralt de Roure (una senyora), Marcel-la Aubert de Pous (Antonieta), Carme Bas (la marquesa), Rogeli Serra (un senyor), Jaume Sans, Manuel Espanyol (uns altres senyors), Pere Armengou (el marquès) i Eudald Serra (el director).

Aquesta és l'única traducció teatral completa que tenim de Maria Carratalà. Es tracta més aviat d'una versió, tal com s’indica a la portada. Una ràpida ullada per la llista dels personatges ja ens ho avança:

Le monsieur de l'Orchestre

Un senyor (des del pati de butaques) Le régisseur

El director

I6. L'exemplar que es conserva a la Biblioteca de Catalunya, publicat dins la col-lecció «La escena Catalana» (núm. 4I4), Llibreria Bonavia, Barcelona, 1935, pertany a la col-lecció de don Artur Sedó i està dedicat per la mateixa Maria Carratalà: «De l’obra important de Tristan Bernard vam triar aquesta obra mestra per fer-la conèixer al nostre públic», resa la dedicatòria. 
Le vicomte de Braisy

Le marquis

Un second monsieur

Une dame du balcon

Mlle. Stephenson (marquise de Chérace)

Mlle. Antoinette Kronska
El vescomte de Brugueroles

El marquès

Un altre senyor

Una senyora (des d'una llotja)

La marquesa de Rocabruna

Senyoreta Antonieta Sistrells

Per tal que els diàlegs no transmetin la sensació que es tracta d'una traducció, a més d'adaptar el antropònims, adapta els topònims, i així l'acció no passa a París sinó a Barcelona; «la petita vila del nord de França» es converteix en «Figueres»; «le théâtre Moncey» passa a ser "un teatre de Vilassar» o l'estada d'un dels personatges a Montpeller es resol com a una estada «fora de Barcelona».

L'habilitat per crear un diàleg àgil, ràpid i proper transmet a la peça sensació de vivesa. L'adaptació al registre oral i popular, adequat al tema i la situació que es tracta, fa fluir un text que basa tota la seva força i comicitat en la paraula.

En seleccionem un fragment per veure la naturalitat i l'agilitat amb què flueix el diàleg a la versió catalana (1935: 5):

\section{Fragment traduït per Maria Carratalà}

La senyora. Sóc jo que li he dit de riure en aquesta escena, perquè el públic es pogués fer càrrec d'aquest riure tan bonic que té. L'autor, en aquella llotja, no està gaire content.

Algunes veus. Calleu! Ss...

La senyora. Vaja, ja no dic res més... L'escena d'amor que ara faran no val gran cosa. En el moment que ell la té abraçada, entra la nena, vull dir la meva filla, i els diu: «Ara ve el marit!». Sort d'ella, si no, el marquès els atrapava.

Un altre senyor. (Des d'un altre rengle de butaques). Senyora vol fer el favor de deixar-nos escoltar la comèdia?... No cal que l'expliqui per endavant. Ja ho anirem veient.

\section{Original}

La dame. C'est moi qui lui ai dit de rire, à ce moment-là, pour montrer comme elle riait bien... L'auteur de la pièce, en bas, dans la baignoire, n'est pas content...

Voix. Chut! Chut!

La dame. Allons! Je vous laisse écouter... Mais la scène d'amour n'est pas très intéressante. Au moment où il la prend dans ses bras, Antoinette, la bonne, ma fille, arrive, en criant : Voilà le mari! Il sera temps.

Un monsieur. Je vous en prie, Madame, laissez-nous écouter la pièce... Nous n'avons pas besoin de vous por nous l'expliquer.

(Bernard 1930: 240) 
D'aquesta obra, se'n va fer una altra representació el dijous 7 de febrer de 1935 a l'Ateneu Empordanès a Barcelona, juntament amb Es rifa un home, comèdia en un acte de Rosa Maria Arquimbau (La Rambla, 4-2-1935).

5 i 6. Davant la mort, d'August Strindberg, i La innocent, d'Henri-René Lenormand (1936)

El 9 de juny de 1936 Maria Carratalà organitza pel Lyceum Club de Barcelona una vetllada cultural on es representen tres peces: Davant la mort, de Strindberg; ${ }^{17}$ Un prometatge, de Txèkhov, i La innocent, de Lenormand. ${ }^{18}$ Malgrat l'afirmació del novel.lista i articulista Domènec Guansé, que assenyala que la traducció de les tres obres és de Maria Carratalà, el cert és que la barcelonina només va traduir la primera i la tercera; la segona va ser traduïda per Lina Sitges, pseudònim d'Artur Carbonell, segons E. Gallén (Real Mercadal 2006: I27, n. 297). I sobre la feina de Carratalà, diu Guansé: «Maria Carratalà, traductora esforçada de les tres obres, ha complert amb molta pulcritud la seva tasca» (La Publicitat, 13-6-1936). Un anònim articulista de La Veu de Catalunya afirmava: «La traducció de les obres representades ens semblà correcta i fidel» (II-6-I936), i en la mateixa línia trobem el comentari d'Emilio Tintorer que a Las Noticias deia: «Esta obrita [La innocent], como el drama de Strindberg Davant la mort han sido correcta y literariamente traducidos por María Carratalá». V. assenyalava a La Noche: «[...] nos ofrecieron esta obra traducida por María Carratalá, con admirables aciertos». Molt més entusiastes van ser les paraules de María Luz Morales, periodista de reconegut renom i traductora: «Las excelentes versiones catalanas de $D a$ vant la mort y de La Innocent débense a María Carratalá, respetuosa y fina traductora» (La Vanguardia, II-6-1936).

17. Era la primera vegada que es representava una obra de Strindberg en català. Anteriorment, els espectadors de la ciutat comtal havien tingut l'oportunitat de veure dues peces de l'autor suec a la dècada dels anys 20: la primera d'elles va ser Créanciers, representada en francès, del 8-II de maig de 1925 per Galas Karsenty; la segona fou El padre (Père), estrenada per la companyia argentina de Matilde Rivera i Enrique Rosas el 8 de gener de 1926 al Teatre Goya (Ferran, 20I0: 60-70).

I8. Lenormand no era un autor desconeguts als escenaris catalans: Els fracassats (Les ratés) s'havia estrenat el 27 de febrer de 1928 al Teatre Novetats, en presència del propi dramaturg, i L'Agulla roja (La Dent rouge) es va estrenar gairebé un any després, el 29 de gener de 1929. Totes dues peces serien representades abans de la guerra per la companyia de Margarita Xirgu: Los fracasados (trad. de Joaquín Montaner), el 23 d'octubre de I928, i L’Agulla roja, el 2 de desembre de I93I (Gallén, 2005: 159). Una obra més de Lenormard, Asia, va arribar al Teatre Novetats el dia II de juliol de 1936, tres anys després de ser estrenada a Madrid. 
A excepció d'aquest darrer comentari, les referències a la traducció i les crítiques són més aviat fredes i minses, comparades amb les que trobàvem als diaris locals de Sitges sobre les representacions anteriors, que no sols opinaven sobre la qualitat literària de la traducció, sinó que proporcionaven fragments dels textos. Cert és que una representació al Prado Suburense era tot un gran esdeveniment per al poble costaner del Garraf, on no hi havia cap altre teatre; en canvi, una representació amateur en un petit teatret a Barcelona, facilment passava desapercebuda enmig d'una ciutat que comptava amb una desena de teatres professionals importants i diversos locals d'amateurs. ${ }^{19}$

A més a més, si som honestos, sembla que l'espectacle no va agradar gaire, especialment les peces traduïdes per Maria Carratalà, no per la traducció en si, sinó perquè Strindberg i Lenormand quedaven molt lluny de l'estètica de la societat republicana de la preguerra. Reprodueixo l'opinió de Joan Cortés, apareguda a Mirador (25-6-1936):

La sessió començà amb Davant la mort, drama en un acte, de Strindberg, traduït per Maria Carratalà. De les tres obres representades, aquesta era la de més difícil encaix en la sensibilitat del nostre públic. No debades Strindberg fou un dels autors més acreditats en aquell temps en les quals el dramatisme més irredemptista i més cellajunt era el que s’enduia les voluntats dels autors i de les seleccions de cada país. Avui, Strindberg queda reculat, reculat fins qui sap on. [...] La segona obra representada fou Un prometatge, d'Anton Txécov (per què hem de transcriure, encara, els noms russos en francès, com constava el d'aquest autor en els programes?), farsa en un acte, traduïda per Lina Sitges. No cal que diguem que aquesta va ésser per a nosaltres la part més bona de la vetllada. [...] La tercera peça va ésser La innocent, de Lenormand — per a nosaltres, teatralment, molt inferior a les altres dues, traduïda també per Maria Carratalà. Indubtablement, si Lenormand s'hi hagués hagut de fer el nom que té, a hores d'ara potser encara no hauríem tingut cap notícia d'ell.

No van ser millors les opinions bolcades a La Veu de Catalunya (II-6-1936) sobre aquesta tercera tanda d'estrenes teatrals al Lyceum Club:

Avui aquesta obra [Davant la mort de Strindberg] ens deixa una mica freds. Es tracta, no menys, que d'un pare avorrit de les seves tres filles, el qual, per alliberar-les de la misèria, no troba cap més solució que calar foc a la casa i aleshores emmetzinar-se ell. [...] La innocent, de H. R. Lenormand, d'un sol acte. «Tota és una noia beneïtona, que parla amb les flors, corre pel camp espellifada i es lliura a fantasies indescriptibles. Un matrimoni desheretat tracta d'induir-la a suprimir la criatura que els roba l'herència d'un parent. [...] A la fi, triomfa la seva bonesa innata, i a través de les boires del seu cervell veu clara la infamia que li havien proposat»

I9. Foguet i Boreu (2005: 36) assenyala que a finals d'agost del 36 es reprèn l'activitat teatral a Barcelona en onze teatres professionals, que comencen a especialitzar-se per gèneres: Teatre Poliorama, Romea, Espanyol, Teatre Nou, Apolo, Barcelona, Novetats, Victòria, Còmic i Tívoli. Els quatre primers representen en català. A més a més, a aquesta llista s'han d'afegir les nombroses sales on es representava teatre amateur.

Caplletra 61 (Tardor, 2016), pp. 37-59 
La selecció de les obres, que seguia com a criteri que fossin textos breus, no va ser gaire encertada: la tria va condicionar la qualitat de les obres que s'hi van representar, de manera que el que es va veure a escena no era el millor de Strindberg, Txèkhov i Lenormand, sinó les seves obres més curtes. El resultat va ser la presència de tres personatges femenins amb problemes psicològics. Això va portar Guansé a acabar el seu article amb la reflexió següent (La Publicitat, I3-6-1936):

El que resulta curiós de la vetllada és que, a desgrat d'ésser el Lyceum Club una entitat femenina, de tots els personatges femenins que ens ha fet desfilar per l'escena no n'hi ha cap que no sigui moralment recusable. ¿Quin esperit irònic o paradoxal, els ha impulsat a oferir-nos en una sola nit, una tan vasta galeria de monstres amb faldilles?

El grup d'actors que va representar Davant la mort estava format per Marcel.la Auber (Adela), Gertrudis Millàs (Teresa), Montserrat Pahissa (Anneta), Josep Mirabent (Antoni) i Rogeli Serra (Senyor Duran).

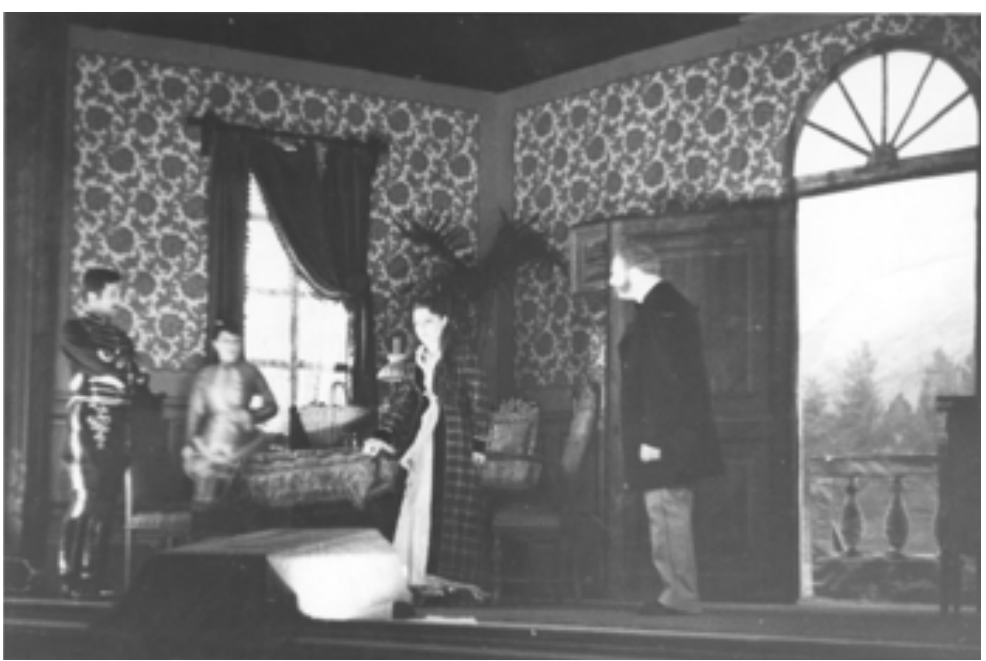

Escena de Davant la mort, de Strindberg

(Fons Artur Carbonell, AMS). 


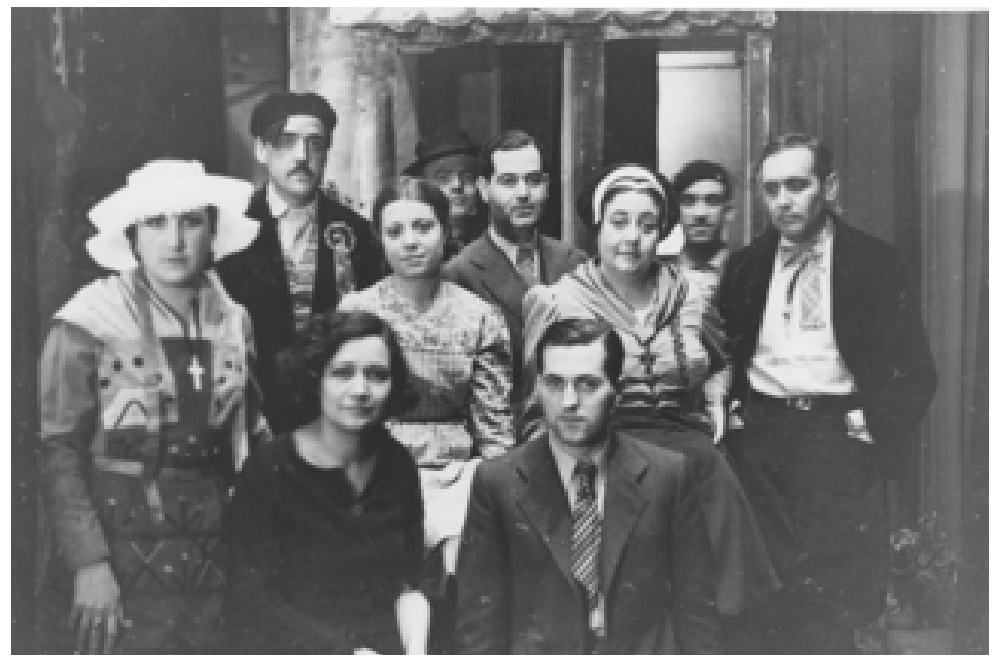

Grup d'actors i Artur Carbonell en La Innocent, de Lenormand

(Fons Artur Carbonell, AMS).

Els actors que van representar La innocent foren Marcel.la Aubert (Tota), Gertrudis Millàs (Genoveva), Josep Mirabent (el noi Balmaz), Montserrat Pahissa (la dona), Daniel Planes (l'home), Manuel Pous (el company), Maria Rosich (l'hostalera) i Rogeli Serra (el vell).

\section{A TALL DE REFLEXIÓ}

Aquesta repassada per la carrera traductològica de Maria Carratalà ens ha permès apropar-nos a una figura oblidada, i treure a la llum alguns fragments de traduccions que eren desconeguts.

Com hem pogut veure, la seva dedicació al món de la traducció teatral comença de la mà d'Artur Carbonell el I930 i es veu estroncada per l'esclat de la Guerra Civil. El seu domini de les llengües francesa i alemanya, el gust per la literatura europea, la formació en escoles refinades, el contacte amb el món artístic i la sensibilitat lingüística per al món de la traducció van fer que col-laborés amb el director sitgetà en sis ocasions.

Si tenim en compte que entre I930 i 1936 Carbonell estrena I4 muntatges, trobem que en un $43 \%$ del seus espectacles va participar Maria Carratalà com a traductora. Ara bé, ¿com s'explica que Artur Carbonell, a la seva conferència memòria (1956), recordi els més mínims detalls de les seves primeres posades en escena i no hi digui res d'ella? 
L'única referència apareix quan ha de parlar sobre la seva arribada al Teatre Studium, gràcies al Lyceum Club del qual ella era presidenta, i diu: «Quiero hacer constar el nombre de María Carratalà, que con tanto interés prestó su colaboración en estas ocasiones de teatro de cámara» (1956). Res més. Amb prou feines dues fredes línies inexcusables i cap referència a la seva tasca traductològica, encara al llarg de la seva conferència rememora Carolina Benaprés, que va traduir per a ell La voix humaine, de Cocteau, i María Luz Morales, de qui diu: «traductora fiel y delicada de algunas obras de mi repertorio" (1956).

El silenci d'Artur Carbonell sobre la tasca de Maria Carratalà com a traductora esdevé un silenci lapidari, un silenci massa sospitós quan emmarquem aquestes dues figures en el marc ideològic que va resultar de la Guerra Civil: vencedors i vençuts. Potser ser dona, republicana, catalanista i activista política d'esquerres era un llast massa pesant per compartir-lo amb les noves amistats sorgides del nou règim.

Teresa Julio

Universitat de Vic - UCC

tjulio@uvic.cat

ORCID 0000-0003-2966-9288

\section{REFERÈNCIES BIBLIOGRÀFIQUES}

Bernard, T. (1930), «Antoinette ou le retour du marquis», dins Théâtre sans directeur, París, Albin Michael.

_(1935) Antonieta o la tornada del marquès, Barcelona, Bonavia. [trad. de M. Carratalà.] Carbonell, A. (1956) «Experiencias y consejos de dirección artística». Conferència feta a l'Institut del Teatre de Barcelona el 20-I2-1956. Fons Artur Carbonell (AMS). Cocteau, J. (1927) Orphée. Tragédie en un acte et un intervalle, París, Librairie Stock. Ferran, F. (20IO) Strindberg a Barcelona. [Treball final de màster, dirigit per E. Gallén, en línia: http://www.recercat.net/bitstream/handle/2072/97277.]

Foguet i Boreu, F. (1998a) «Lyceum Club de Barcelona. Una aposta per un "teatre intel.ligent" (1934-1937)", Serra d'Or, 465, pp. 62-65.

— (1998b) «El teatre amateur català en temps de guerra i revolució (1936-1939)», Els Marges, 62, pp. 7-40.

- (2005) Teatre, guerra i revolució. Barcelona, 1936-39, Barcelona, Publicacions de l'Abadia de Montserrat.

— (2006) «Florentina, una peça inèdita de Maria Carratalà», Pausa, 25, pp. 65-95. 
GalléN, E. (2005) «H. R. Lenormand en el teatre català d'entreguerres», dins Gèneres i formes en la literatura catalana d'entreguerres (I9I8-I939), Lleida, Punctum, pp. I45-167.

- (2012) «Jean Cocteau a l'escena catalana (1917-1966)», Caplletra, 53, pp. 35-64.

Goethe, J. W. (194I) Egmont, Germany, Reclam-Drud.

Pellerin, J.-V. (1929) Têtes de rechage. Spectacle en trois parties, París, Calmann-Lévy, Éditeurs.

Real Mercadal, N. (2006) Dona i literatura a la Catalunya de preguerra, Barcelona, Publicacions de l'Abadia de Montserrat.

SAmsó, J. (1994) La cultura catalana: entre la clandestinitat i la represa pública, vol. I, Barcelona, Publicacions de l'Abadia de Montserrat. 